\title{
The analysis of slip tendency of major tectonic faults in Germany
} Luisa Röckel ${ }^{1}$, Steffen Ahlers², Birgit Müller ${ }^{1}$, Karsten Reiter ${ }^{2}$, Oliver Heidbach ${ }^{3,4}$, Andreas Henk ${ }^{2}$, Tobias Hergert ${ }^{2}$, Frank Schilling ${ }^{1}$

${ }^{1}$ Institute of Applied Geosciences, TU Darmstadt, 64287 Darmstadt, Germany

$5 \quad$ Institute of Applied Geosciences, KIT, 76131 Karlsruhe, Germany

${ }^{3}$ Helmholtz Zentrum Potsdam, Deutsches GeoForschungsZentrum GFZ, 14473 Potsdam, Germany

${ }^{4}$ Institute of Applied Geosciences, TU Berlin, 10587 Berlin, Germany

Correspondence to: Luisa Röckel (Luisa.roeckel@kit.edu)

Abstract.Seismic hazard during subsurface operations is often related to the reactivation of pre-existing tectonic faults. The analysis of the slip tendency, i.e. the ratio of shear to normal stress acting on the fault plane, allows an assessment of the reactivation potential of faults. We use the total stresses that result from a large-scale 3D geomechanical-numerical model of Germany and adjacent areas to calculate the slip tendency for three 3D fault geometry sets with increasing complexity. This allows to draw general conclusions about the influence of the fault geometry on the reactivation potential.

In general, the fault reactivation potential is higher in Germany for faults that strike NW-SE and NNE-SSW. Due to the

15 prevailing normal stress regime in the geomechanical-numerical model results, faults dipping at an angle of about $60^{\circ}$ generally show higher slip tendencies in comparison to steeper or shallower dipping faults. Faults implemented with a straight geometry show higher slip tendencies than those represented with a more complex, uneven geometry. Pore pressure has been assumed as hydrostatic and has shown to have a major influence on the calculated slip tendencies. Compared to slip tendency values calculated without pore pressure, the consideration of pore pressure leads to an increase of slip tendency of up to $50 \%$. The qualitative comparison of the slip tendency with the occurrence of seismic events with moment magnitudes $\mathrm{M}_{\mathrm{w}}>3.5$ shows an overall good spatial correlation between areas of elevated slip tendencies and seismic activity for one of the investigated fault sets.

\section{Introduction}

Seismic activity is a crucial aspect for many subsurface constructions and activities such as the production of oil and gas, coal mining, geothermal energy production, the storage of gas or the construction and save long term operation of a nuclear waste repository. The occurrence of seismic activity is closely linked to the presence of pre-existing tectonic faults and their reactivation (Sibson, 1985). To estimate the potential to trigger seismic events, knowledge about the reactivation potential of tectonic faults is essential (Moeck et al., 2009; Worum et al., 2004). Slip on a fault occurs when the resolved shear stress $\tau$ is larger than the frictional resistance $\tau_{\mathrm{f}}$ (Sibson, 1974; Jaeger et al., 2011):

$30 \tau \geq \tau_{f}=C+\mu \cdot \sigma_{\text {neff }}$ 
https://doi.org/10.5194/egusphere-2022-26

Preprint. Discussion started: 8 March 2022

(c) Author(s) 2022. CC BY 4.0 License.

(c) (i)

where $\mathrm{C}$ is the fault cohesion, $\mu$ is the coefficient of static friction and $\sigma_{\text {neff }}$ the effective normal stress on the fault. The relevant parameters for the assessment of the fault reactivation potential are therefore: 1) The stress tensor to estimate $\tau$ and the absolute normal stress $\sigma_{\mathrm{n}}$; 2) The pore pressure required for the calculation of $\sigma_{\text {neff }}$ 3) The fault orientation that influences the magnitudes of $\sigma_{\mathrm{n}}$ and $\tau$; 4) The frictional fault properties $\mathrm{C}$ and $\mu$ that describe the fault's material.

35 The stress tensor in previous works has mainly been estimated utilizing stress inversion (McFarland et al., 2012; Yukutake et al., 2015; Ferrill et al., 2020), point-wise stress data from field observations (Neves et al., 2009; Lee and Chang, 2009; Moeck et al., 2009) or using Monte Carlo Simulation (Healy and Hicks, 2022) for 2D lineaments and in some cases 3D fault geometries. Worum et al. (2004) calculated the 3D stress tensor with an analytical model and used it for the estimation of the fault reactivation potential of 3D faults of the Roer Graben. Stress tensor estimates from 3D geomechanical-numerical models

40 have been used to determine fault reactivation potential on regional scales, e.g. for the Upper Rhine Graben (Peters, 2007) or the Val d'Agri (Italy) (Vadacca et al., 2021), but this has not been achieved for entire Germany.

Here, we use the first 3D geomechanical-numerical model of Germany by (Ahlers et al., 2021b) that provides an estimate of the 3D stress tensor that is variable with depth and lateral extent (Cornet and Röckel, 2012) due to inhomogeneous density and elastic rock properties. Furthermore, we compile three sets of 3D fault geometries with increasing complexity and use the

45 stress tensor from the Germany model to predict the fault reactivation potential. The fault sets can be used not only to derive a first order estimation of the fault reactivation potential, but also to highlight the effect of fault geometry on the fault reactivation potential. We also investigate the impact of hydrostatic pore pressure as well as assumed overpressure on the reactivation potential estimates and compare our results with the spatial distribution of seismic events with moment magnitudes $\mathrm{M}_{\mathrm{w}} \geq 3.5$.

\section{$50 \quad 2 \quad$ Data \& Method}

\subsection{D Stress State}

The stress tensor used for assessment of the fault reactivation potential is derived from the 3D geomechanical-numerical model of Germany of Ahlers et al. (2021a) that covers Germany and adjacent areas and provides a continuum mechanics based prediction of the stress tensor. The purely elastic finite element (FE) model comprises seven mechanical units (sediments, four

55 upper crustal units, the lower crust and parts of the lithospheric mantle) with a lateral grid resolution of $6 \times 6 \mathrm{~km}^{2}$ and a vertical resolution decreasing from $800 \mathrm{~m}$ within the sediments to $7500 \mathrm{~m}$ at the model base. Each unit is characterized by its respective density, Young's modulus and Poisson's ratio (Ahlers et al., 2021a). The model is calibrated with stress magnitude data from the magnitude database by Morawietz et al. (2020) and compared with stress orientations from the World Stress Map database (Heidbach et al. 2016). The resulting best-fit model provides the 3D absolute stress tensor $\sigma_{i j}$ within the model domain (Ahlers

60 et al., 2021a), i.e. for Germany and adjacent areas. In order to consider effective stresses, we assume a hydrostatic pore pressure. Even though overpressure is well documented for the Molasse Basin (Drews et al., 2018; Müller et al., 1988), there is not enough spatial information on pore pressure available to justify the usage of different pore pressure gradients in our analysis. 
https://doi.org/10.5194/egusphere-2022-26

Preprint. Discussion started: 8 March 2022

(c) Author(s) 2022. CC BY 4.0 License.

(c) (i)

\subsection{Generation of fault data sets}

A spatially comprehensive collection of 2D fault lineaments in Germany has been compiled by Schulz et al. (2013). 3D fault geometries are available on a regional scale for some regions in Germany, such as the North German Basin (Bundesanstalt für Geowissenschaften und Rohstoffe, 2021), the Molasse Basin (GeoMol Team, 2015) in South Germany or in the model of Saxony (Geißler et al., 2014). However, there are no comprehensive 3D fault geometry compilations available for Germany. We created a total of three fault sets of increasing complexity. The first fault set is based the 2D fault collection by Schulz et al. (2013) that comprises the 2D lineaments of 900 faults in Germany. The faults used in the second fault set have been chosen according to selection criteria. The selection criteria comprise the length of the fault ( $\geq 250 \mathrm{~km}$ ), the horizontal displacement ( $\geq 10 \mathrm{~km}$ ), the vertical displacement $(\geq 2.5 \mathrm{~km})$ and the seismic activity of the fault (since $800 \mathrm{CE}$ or later). The application of the selection criteria let to a final compilation of 55 faults. For these faults the tectonic regime, namely strike-slip, normal faulting or thrust faulting was known from a data collection of (Suchi et al., 2014; Agemar et al., 2016) or respective literature. For the third fault set, we used geological and seismic cross sections in the depth domain to compile data on the 3D geometry of the selected faults. For 23 faults, cross sections with sufficient vertical extent were available. Based on the three described fault sets we generated three different 3D geometry sets of increasing complexity for slip tendency calculation:

1. Vertical fault set: All 900 faults of the fault catalogue (Agemar et al., 2016) were implemented as $90^{\circ}$ dipping faults extending to the base of the lower crust.

2. Andersonian fault set: The 55 selected faults have been implemented depending on their Andersonian fault type as normal faults, thrust faults or strike-slip faults. For normal faults a dip angle of $60^{\circ}$ was assigned, for thrust faults of $30^{\circ}$ and for strike-slip of $90^{\circ}$. The faults reach the base of the lower crust. The supplementary Table S1 lists the implemented faults with a corresponding ID.

3. Semi-realistic fault set: For 23 faults, a more complex geometry on the basis of seismic and geological cross sections is used. The depth of the faults is not constant as in the Vertical and Andersonian fault sets, but is chosen in accordance with the depths given in the sections used. The vertical cross sections used for the generation of the semi-realistic fault set are compiled in Table 1. The quantity of available cross sections per fault varied considerably. For many faults, only one cross section was available leading to a uniform geometry over the entire length of the fault.

Table 1 Sources with suitable geological and seismic cross sections for the generation of semi-realistic fault geometries and the specific faults they were used for.

\begin{tabular}{ll}
\hline \multicolumn{1}{c}{ Fault } & \multicolumn{1}{c}{ Source } \\
\hline Albstadt Shear Zone & Derived from Reinecker and Schneider, 2002 \\
\hline Allertal Lineament & Littke et al., 2008 \\
\hline Alpine Thrust & Brückl et al., 2007 \\
\hline Finne Fault & Reinhold, 2005 \\
\hline Franconian Line & Reinhold, 2005 \\
\hline Gardelegen Fault & Littke et al., 2008, Reinhold, 2005 \\
\hline Haldesleben Fault & Littke et al., 2008, Reinhold, 2005 \\
\hline
\end{tabular}


https://doi.org/10.5194/egusphere-2022-26

Preprint. Discussion started: 8 March 2022

(c) Author(s) 2022. CC BY 4.0 License.

(c) (i)

\begin{tabular}{ll}
\hline Harz Northern Boundary fault & Reinhold, 2005 \\
\hline Hunsrueck Southern Border fault & Henk, 1993 \\
\hline Kyffhäuser Fault & Reinhold, 2005 \\
\hline Lausitz Escarpement & Reinhold, 2005 \\
\hline Lausitz Thrust & Behr et al., 1994 \\
\hline Midi-Aachen Thrust & Ribbert and Wrede, 2005, Cazes et al., 1985 \\
\hline Osning Fault & Duin et al., 2006, Drozdzewski and Dölling, 2018 \\
\hline Roer Graben & Duin et al., 2006, Geluk et al., 1994 \\
\hline Siegen Thrust & Franke et al., 1990 \\
\hline Swabian Lineament & Pfiffner, 2017 \\
\hline Teisseyre-Tornquist Zone & Narkiewicz et al., 2015 \\
\hline Upper Rhine Graben & Brun et al., 1992, GeORG-Projektteam, 2013 \\
\hline Wittenberg Fault & Reinhold, 2005
\end{tabular}

\subsection{D Slip tendency analysis}

To estimate the fault reactivation potential we use definitions and terms of Morris et al. (1996). Assuming that cohesion can be neglected, they defined the parameter slip tendency as the ratio between $\tau$ and $\sigma_{n}$. We use this definition as a first slip tendency type:

$95 T_{s}=\frac{\tau}{\sigma_{n}}$

We further define three additional slip tendency parameters for our analysis. $T_{\text {Seff }}$ considers $\sigma_{\text {neff }}$ stress that takes the influence of pore pressure on $\sigma_{\mathrm{n}}(\mathrm{Jaeger}$ et al., 2011) into account.

$T_{\text {seff }}=\frac{\tau}{\sigma_{\text {neff }}}$

A normalization to $\mu$ has been used for example by Peters (2007) and is additionally calculated as $T_{\text {Snorm }}$ and $T_{\text {Snormeff }}$. We

100 choose $\mu$ as 0.57 which is in the middle of the range reported by Jaeger et al. (2011). For $T_{\text {Snorm }}$ and $T_{\text {Snormeff }}$ slip is likely to occur if they approach values around 1 or larger.

$T_{\text {Snorm }}=\frac{\frac{\tau}{\sigma_{n}}}{\mu}$

$T_{\text {Snormeff }}=\frac{\frac{\tau}{\sigma_{\text {neff }}}}{\mu}$

The pore pressure $\mathrm{P}_{\mathrm{p}}$ for the calculation of $\sigma_{\text {neff }}$ is computed from the depth $\mathrm{z}$ [m] (which is the true vertical depth below the topographic surface of the German stress model), gravity $g\left[9.81 \mathrm{~m} \mathrm{~s}^{-2}\right]$ and the fluid density $\rho\left[1000 \mathrm{~kg} \mathrm{~m}^{-3}\right]$ :

$P_{p}=\rho \cdot g \cdot z$ 
https://doi.org/10.5194/egusphere-2022-26

Preprint. Discussion started: 8 March 2022

(c) Author(s) 2022. CC BY 4.0 License.

(c) (1)

To estimate the slip tendencies, the fault geometries are discretized as surfaces with triangles with a side length of $800 \mathrm{~m}$. Then the 3D stress tensor components from the geomechanical-numerical model of Ahlers et al. (2021b) are mapped on the corner nodes of the triangles using Tecplot 360 EX v2019 and the AddOn Geostress (Heidbach et al., 2020). The mean stress tensor

110 of the three nodes is multiplied with the normal vector of each triangle to estimate $\tau$ and $\sigma_{\mathrm{n}}$. With the TVD and the derived hydrostatic pore pressure the four slip tendency parameters are calculated.

\section{Results}

\subsection{Vertical fault set}

The results for the Vertical fault set are shown for all four slip tendency parameters in Fig. 1. As the faults are vertical, only

115 values for one depth section can be shown in map view. Results near the surface are visualized. $\mathrm{T}_{\mathrm{S}}$ of the Vertical fault set ranges mainly between 0 and 0.5 (histograms are shown in Fig. S2). Higher $\mathrm{T}_{\mathrm{S}}$ values are reached for the uppermost parts of some faults as can be seen in Fig. 1 (a). With increasing depth $\mathrm{T}_{\mathrm{S}}$ decreases rapidly to nearly 0 for all faults. Faults striking NNE-SSW and NW-SE show elevated $T_{S}$ values in the uppermost parts of the faults when compared to faults of other strike directions.

$120 \mathrm{~T}_{\text {Seff }}$ is higher than $\mathrm{T}_{\mathrm{S}}$ and ranges mainly between 0 and $0.7 . \mathrm{T}_{\text {Seff }}$ is highest in the uppermost fault parts and decreases rapidly with increasing depth as well. NW-SE and especially NNE-SSW striking faults show higher $\mathrm{T}_{\text {Seff }}$ than faults of other strike. $\mathrm{T}_{\text {Snorm }}$ values mainly range between 0 and 0.7 and $\mathrm{T}_{\text {Snormeff }}$ ranges mostly between 0 and 1 . The same trends for depth and fault strike apply as for $\mathrm{T}_{\mathrm{S}}$ and $\mathrm{T}_{\text {Seff. }} \mathrm{T}_{\text {Snorm }}$ and $\mathrm{T}_{\text {Snormeff }}$ are however higher in the uppermost parts of the faults than $\mathrm{T}_{\text {Seff. }}$. 
https://doi.org/10.5194/egusphere-2022-26

Preprint. Discussion started: 8 March 2022

(c) Author(s) 2022. CC BY 4.0 License.

EGUsphere

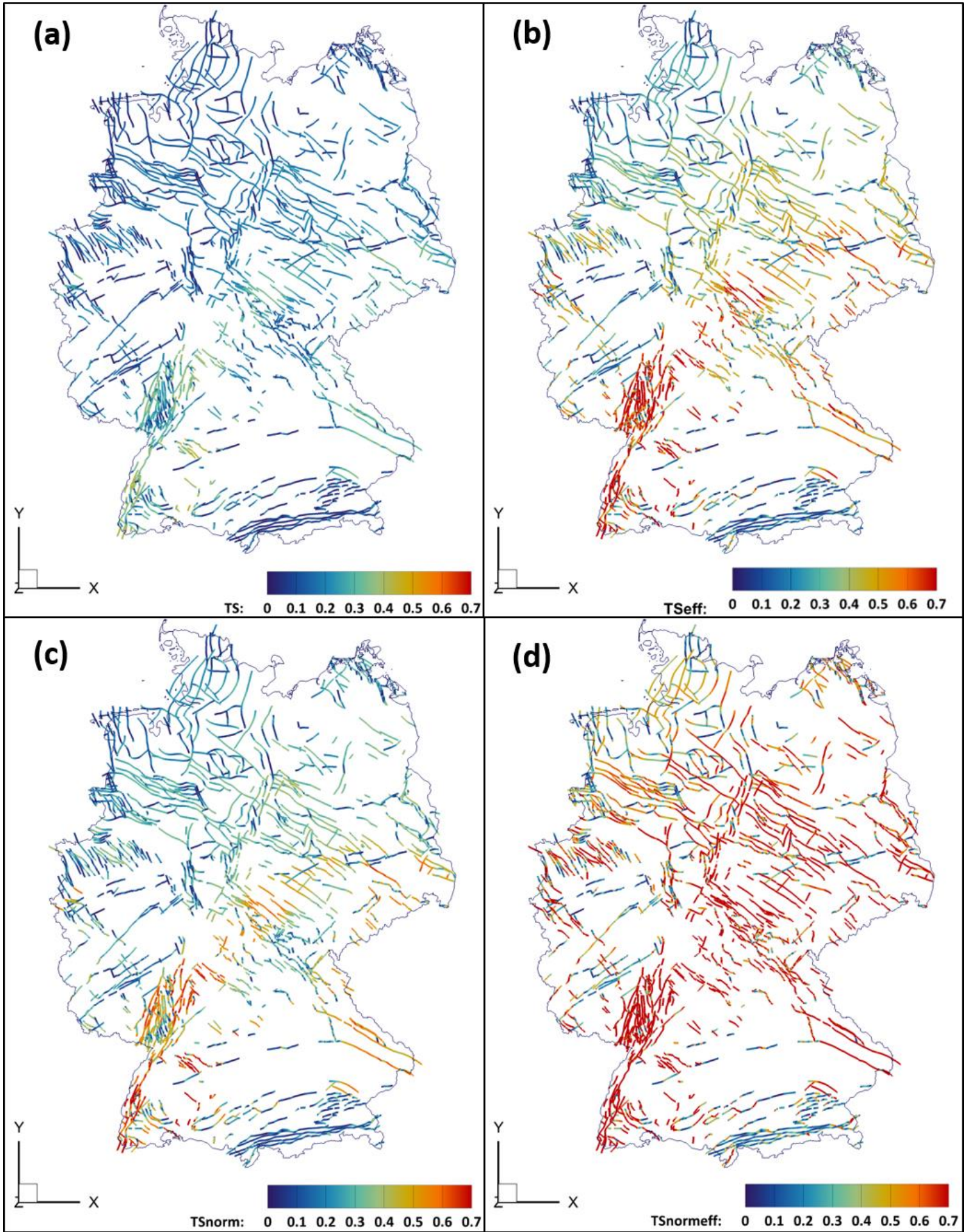


https://doi.org/10.5194/egusphere-2022-26

Preprint. Discussion started: 8 March 2022

(c) Author(s) 2022. CC BY 4.0 License.

(c) (i)

125 Fig. 1 Topview of the slip tendency of the vertical fault set calculated for four cases. Due to the vertical nature of the faults only the uppermost parts of the faults are visible. (a) $T_{S}$; (b) $T_{\text {Seff }}$ (with effective normal stresses); (c) $T_{\text {Snorm }}$ (normalized to a coefficient of friction of 0.57 ); (d) TSnormeff (with effective normal stresses and normalized to a coefficient of friction of 0.57 ) (c) EuroGeographics for the administrative boundaries

\subsection{Andersonian fault set}

130 The resulting slip tendencies of the Andersonian fault set are shown for all four slip tendency types in Fig. 2 (additional histograms are given in Fig. S3). TS ranges mainly between 0 and 0.2. Only the uppermost parts of some NNW-SSE and NESW striking faults such as the Upper Rhine Graben (URG), the Albstadt Shear Zone and the Landshut-Neuoetting Fault show slightly higher values.

$\mathrm{T}_{\text {Seff }}$ mostly ranges between 0 and 0.4 . Only $5 \%$ of the values are higher than 0.4 . $\mathrm{T}_{\text {Seff }}$ is generally elevated for faults and fault

135 segments striking in NNE-SSW and NW-SE direction such as the URG, the Franconian Line, the Albstadt Shear Zone, the Wittenberg Fault, the Rheinsberg Through, the Landshut-Neuoetting Fault and the Roer Graben. The influence of fault strike direction is especially prominent for faults with segments of varying orientation. The NW-SE striking parts of the Rheder Moor-Blenhorst Fault show elevated $\mathrm{T}_{\text {Seff }}$ values when compared to the more WNW-ESE striking segments of the fault. For strike-slip faults, $T_{\text {Seff }}$ strongly decreases within the uppermost fault parts and keeps decreasing with increasing depth as shown

140 for parts of the Albstadt Shear Zone in Fig. 3 (a). $\mathrm{T}_{\text {Seff }}$ slightly increases with depth after the initial strong decrease for some normal and thrust faults. This is shown for the Midi-Aachen-Thrust in Fig. 3 (b). $T_{\text {Snorm }}$ ranges mainly between 0 and 0.3 and shows an overall similar behavior to $\mathrm{T}_{\text {Seff. }}$. While the high $\mathrm{T}_{\text {Snormeff }}$ values reach up to 1.0 , areas with low $\mathrm{T}_{\text {Snormeff }}$ show values in the same range as for the other three slip tendency parameters. The spatial distribution of areas of low and high $\mathrm{T}_{\text {Snormeff }}$ values is similar to $\mathrm{T}_{\text {Snorm }}$ and $\mathrm{T}_{\text {seff. }}$ 
https://doi.org/10.5194/egusphere-2022-26

Preprint. Discussion started: 8 March 2022

(c) Author(s) 2022. CC BY 4.0 License.

EGUsphere

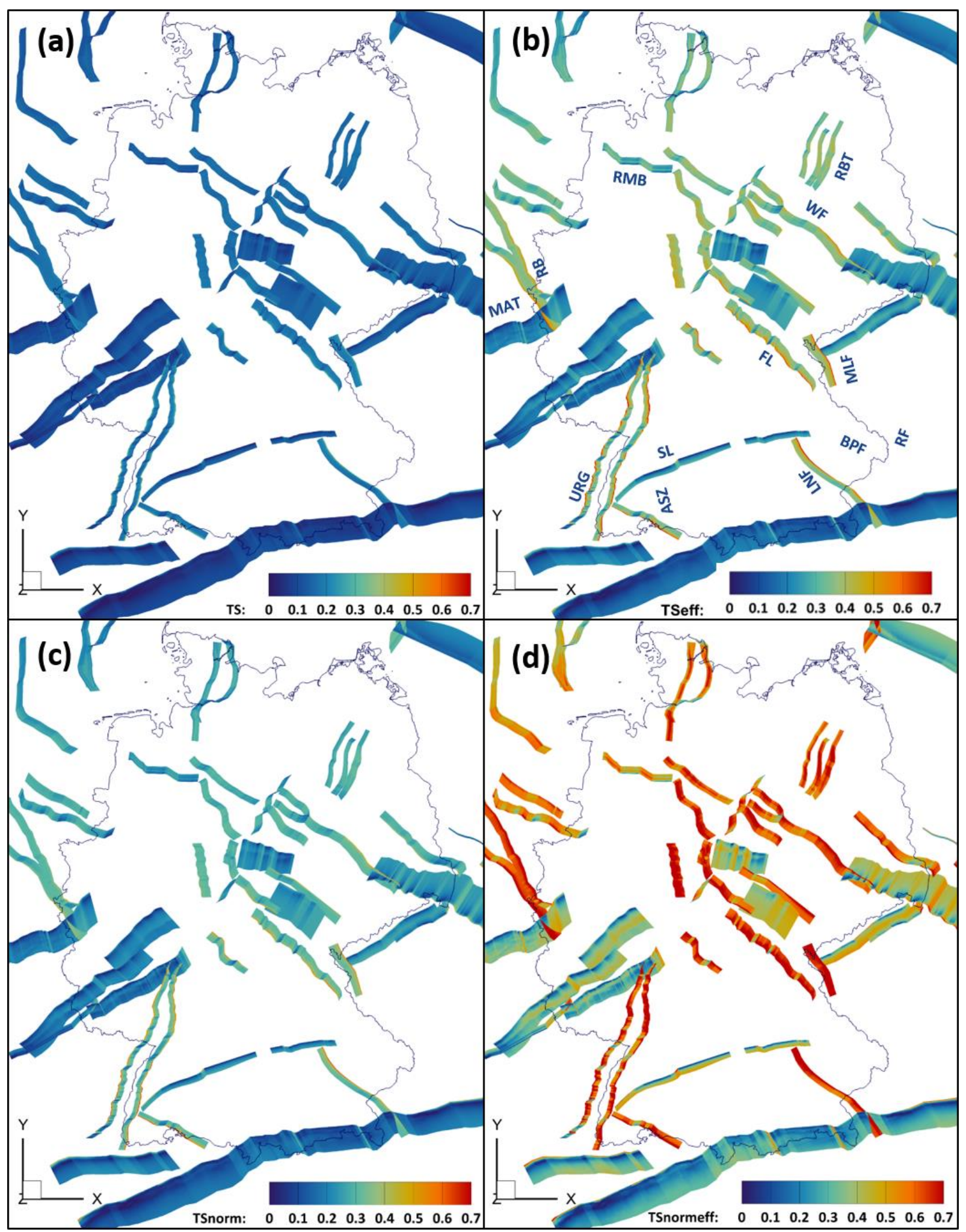


Fig. 2 Topview of the slip tendency of the Andersonian fault set calculated for four slip tendency types. (a) $\mathbf{T}_{\mathbf{S}}$; (b) $\mathbf{T}_{\mathrm{seff}}(\mathrm{with}$ effective normal stresses); (c) $T_{\text {Snorm }}$ (normalized to a coefficient of friction of 0.57 ); (d) $\mathbf{T}_{\text {Snormeff }}$ (with effective normal stresses and normalized to a coefficient of friction of 0.57 )

ASZ: Albstadt Shear Zone (not visible in map view due to the vertical geometry); BPF: Bavarian Pfahl Fault; FL: Franconian Line; LNF: Landshut-Neuoetting Fault; MAT: Midi-Aachen Thrust; MLF: Mariánské Lázne ; URG: Upper Rhine Graben; RB: Roer Basin; RBT: Rheinsberg Through; RF: Rodl fault; RMB: Rheder Moor-Blenhorst Fault; SL: Swabian Lineament; WF: Wittenberg Fault

155 C) EuroGeographics for the administrative boundaries
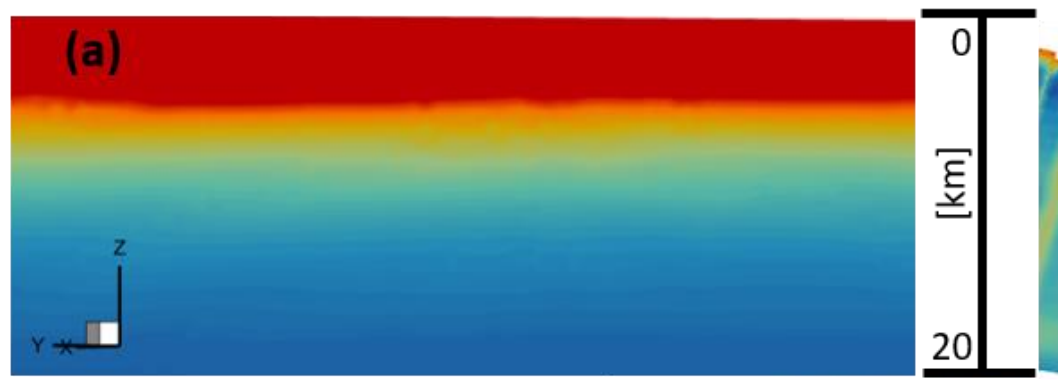

(b)

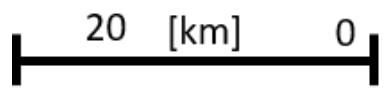

TSeff:
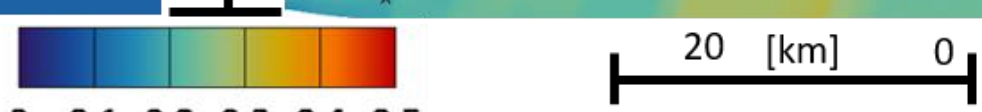

Fig. 3 Vertical section of $T_{\text {Seff }}$ along faults. (a) $\mathbf{T}_{\text {Seff }}$ of a northern part of the Albstadt Shear Zone decreases over the entire depth; (b) $T_{\text {Seff }}$ of an eastern part of the Midi-Aachen Thrust slightly increases again (after an initial strong decrease) as indicated by the shift from blue to greenish colors in greater depths. Colorbar applies to both (a) and (b)

\subsection{Semi-Realistic Fault Set}

Fig. 4 shows the results of the slip tendency calculations for the Semi-Realistic fault set additional histograms are shown in Fig. S4. $T_{S}$ ranges mainly between 0 and 0.2 . For the Semi-Realistic fault set, the NNE-SSW and NW-SE striking faults show elevated $\mathrm{T}_{\mathrm{S}}$ compared to faults of other orientations. The highest $\mathrm{T}_{\mathrm{S}}$ can be observed at the uppermost steeply dipping sections of the URG, the Franconian Line, the Albstadt Shear Zone, the Wittenberg Fault and the Roer Graben. For most faults, $T_{S}$ decreases with increasing depth. However, most faults are significantly less deep than in the Andersonian fault set.

$\mathrm{T}_{\text {Seff }}$ ranges mainly between 0 and 0.4 with $5 \%$ of values 0.5 or higher. Faults striking in NNW-SSE and NE-SW direction such as the URG, the Franconian Line, the Albstadt Shear Zone, the Wittenberg Fault and the Roer Graben show elevated $\mathrm{T}_{\text {Seff }}$ as compared to faults of other strike directions. This influence is especially noticeable for the Franconian Line where the WNW-ESE striking segments of the fault show lower $\mathrm{T}_{\text {Seff }}$ than the NNW-SSE striking ones. For sections of the uppermost parts of the URG and the Roer Graben $T_{\text {Seff }}$ exceeds values of 1 . The decrease in $T_{\text {Seff }}$ with increasing depth is especially prominent for faults that have been implemented with a listric geometry (Such as the URG or the Hunsrueck Southern Border Fault). While the listric URG geometry shows some of the highest $\mathrm{T}_{\text {Seff }}$ values for the Semi-Realistic fault set in its uppermost parts, $T_{\text {Seff }}$ decreases drastically with depth. The same decrease can be observed for the listric Hunsrueck Southern Border Fault. In contrast, $\mathrm{T}_{\text {Seff }}$ increases drastically in the lowermost part of the Swabian Lineament after a steady decrease of $\mathrm{T}_{\text {Seff }}$ with increasing depth for the most part of the fault. 
https://doi.org/10.5194/egusphere-2022-26

Preprint. Discussion started: 8 March 2022

(c) Author(s) 2022. CC BY 4.0 License.

(c) (i)

$\mathrm{T}_{\text {Snorm }}$ mainly ranges between 0 and 0.4 The $\mathrm{T}_{\text {Snorm }}$ distribution is almost identical to the one of $\mathrm{T}_{\text {Seff. }} \mathrm{T}_{\text {Snormeff }}$ mainly ranges between 0 and 0.8 . The high $\mathrm{T}_{\text {Snormeff }}$ values mainly occur on the NW-SE and NNE-SSE striking faults while the areas with low $\mathrm{T}_{\text {Snormeff }}$ show values similar to the other slip tendency types in the respective areas. 
https://doi.org/10.5194/egusphere-2022-26

Preprint. Discussion started: 8 March 2022

(c) Author(s) 2022. CC BY 4.0 License.

EGUsphere

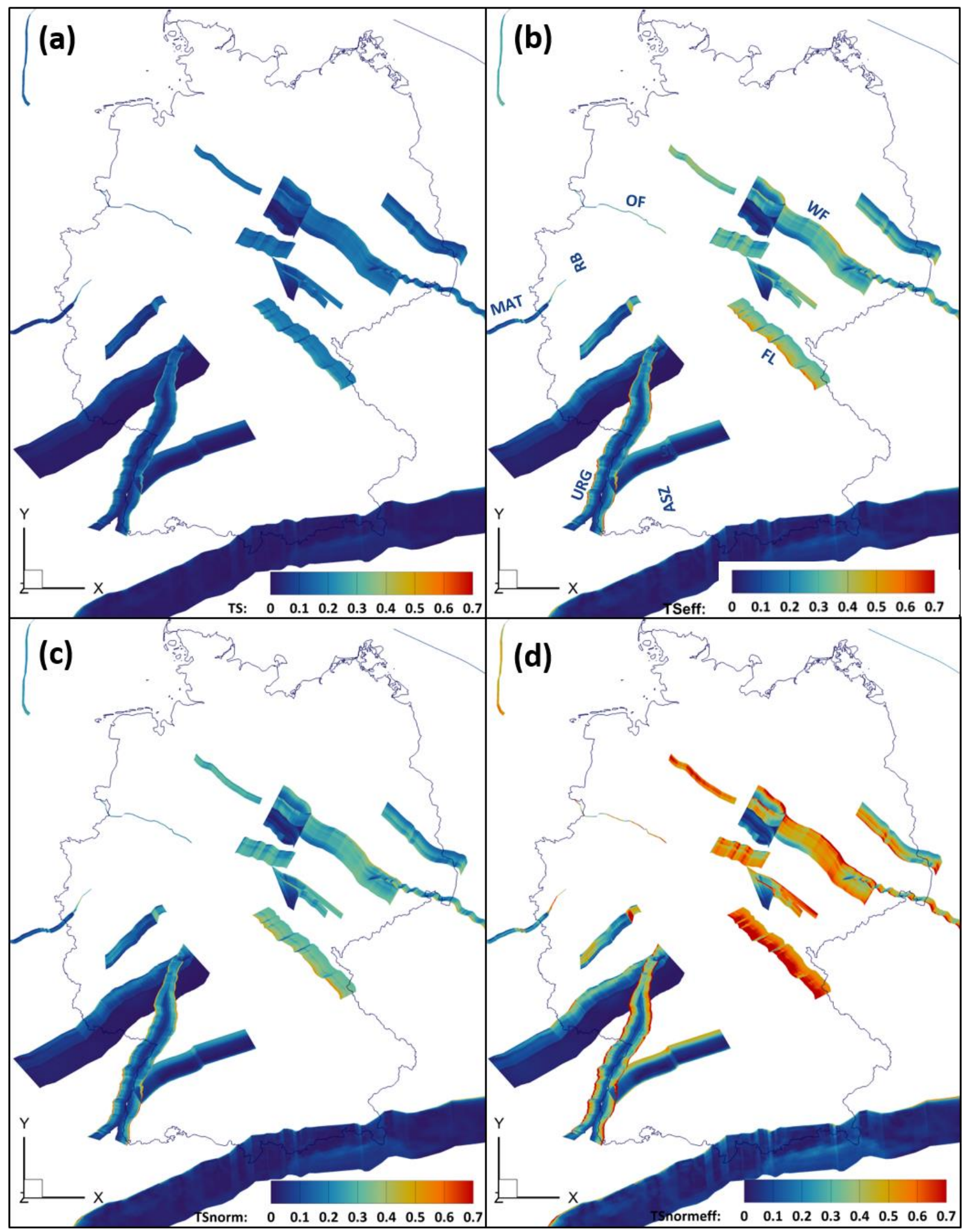


https://doi.org/10.5194/egusphere-2022-26

Preprint. Discussion started: 8 March 2022

(c) Author(s) 2022. CC BY 4.0 License.

(c) (i)

180 Fig. 4 The semi-realistic fault geometries are color-coded by their slip tendency for four cases. (a) TS; (b) TSeff (with effective normal stresses); (c) TSnorm (normalized to a coefficient of friction of 0.57); (d) TSnormeff (with effective normal stresses and normalized $\begin{array}{llllll}\text { to } & \text { a } & \text { coefficient } & \text { of } & \text { friction } & \text { of }\end{array}$ FL: Franconian Line; MAT: Midi-Aachen Thrust; OF: Osning Fault; URG: Upper Rhine Graben; RB: Roer Basin; WF: Wittenberg

Fault

(C) EuroGeographics for the administrative boundaries

\section{Discussion}

\subsection{Influence of fault strike on slip tendency}

To investigate the influence of the spatial orientation of the faults on the slip tendency, we prepared scatter plots of $\mathrm{T}_{\text {seff }}$ as a function of fault strike for all faults of each of the three fault sets (Fig. 5). The normal faults, thrust faults and strike-slip faults of the Andersonian set are displayed in separate subfigures (Fig. 5 (b), (c) and (d) respectively).

Overall, the minimum $\mathrm{T}_{\text {Seff }}$ values occur consistently at strikes of $75^{\circ}$ for all fault types i.e. the reactivation potential is generally the lowest for ENE-WSW striking faults. Vertical faults also show a low reactivation potential on NNW-SSE striking segments (corresponding to strikes of $165^{\circ}$ ). The maximum $\mathrm{T}_{\text {seff }}$ occurs for strikes of $5^{\circ}-25^{\circ}$ for all fault types i.e. the reactivation potential is generally highest for N-S to NNE-SSW striking faults. The vertical faults also have a high reactivation potential for NW-SE strikes, the Andersonian normal faults for NNW-SSE striking segments.
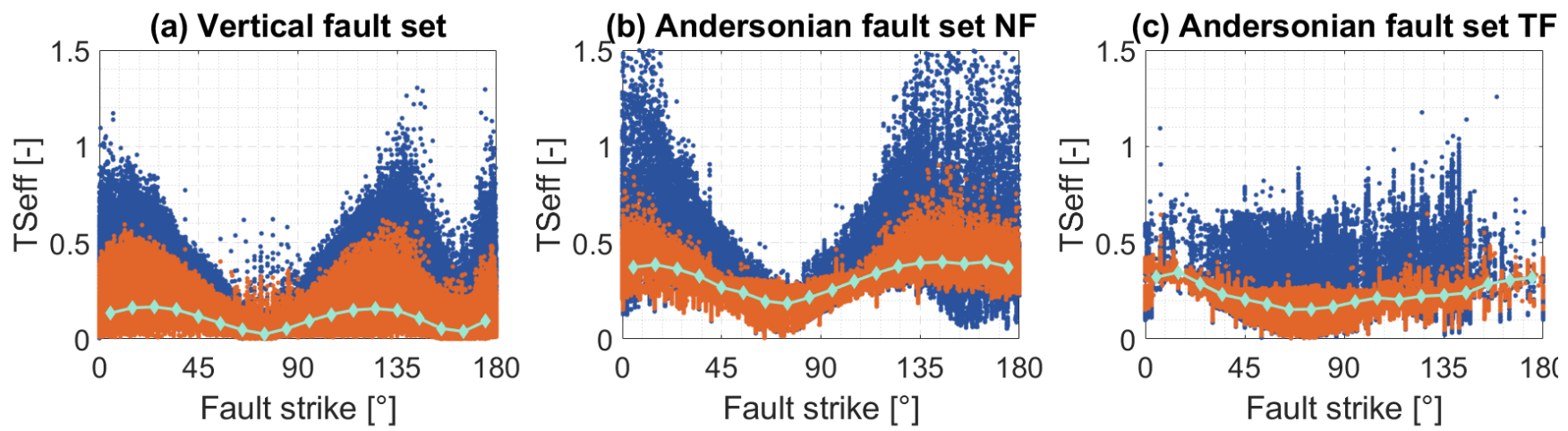

(d) Andersonian fault set SS
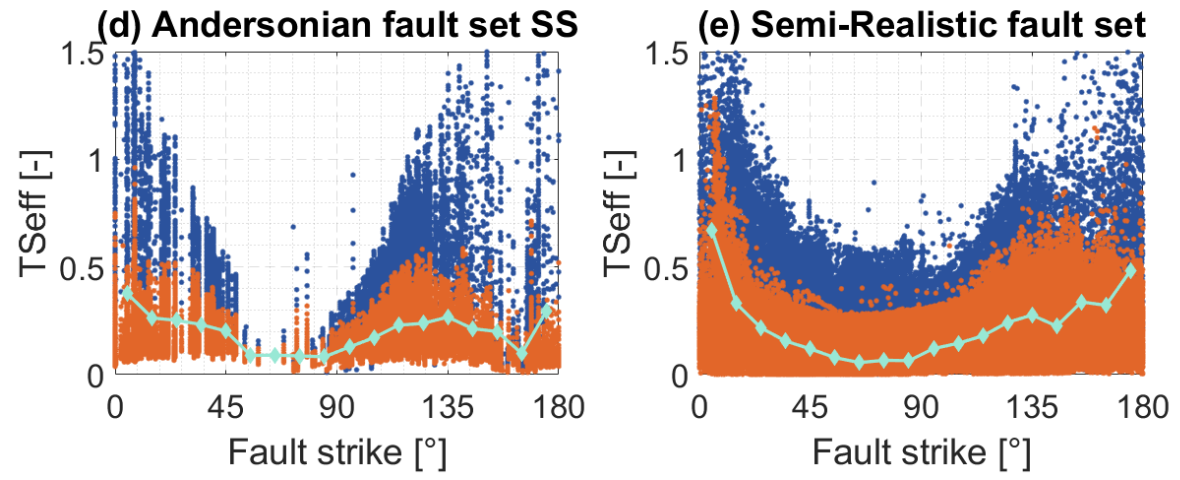

- Strike-slip regime

Normal faulting regime Mean TSeff

Fig. 5 Scatterplots showing $T_{\text {Seff }}$ and the fault strike of each node of the fault mesh. Additionally, the stress regime the data points are subjects to is indicated by its color (blue for strike-slip regime, orange for normal faulting regime). The mean $\mathrm{T}_{\text {Seff }}$ in $10^{\circ}$ fault strike steps is plotted as a mint colored line. (a) vertical fault set; (b) normal faults of the Andersonian fault set; (c) Thrust faults of the Andersonian fault set; (d) Strike-slip faults of the Andersonian fault set; (e) Semi-Realistic fault set 
https://doi.org/10.5194/egusphere-2022-26

Preprint. Discussion started: 8 March 2022

(c) Author(s) 2022. CC BY 4.0 License.

(c) (1)

\subsection{Influence of Depth and shear stress on slip tendency}

Four all three fault sets, a strong decrease in the slip tendencies can be observed from the surface to a depth of 5-10 km as is shown in Fig. 6 and Fig. 7 for the Vertical and Andersonian fault set, respectively. In greater depths, slip tendency gradient is low. This is the case for all four slip tendency types. For the Vertical fault set (Fig. 6), slip tendency decreases steadily for all four slip tendency types with the exception of a dent between $32 \mathrm{~km}$ and $38 \mathrm{~km}$. However, since only very few fault segments reach this depth, the influence of fault strike strongly superimposes the depth dependency for these depths. For the Andersonian fault set (Fig. 7), the same trends apply in general as for the Vertical fault set. However, for the thrust and normal faults the initial strong decrease in slip tendency occurs within the uppermost 3-4 km. In this depth, the stress regime switches from a strike-slip regime to a normal faulting regime in most parts of the model. The slip tendencies of the strike-slip faults are generally higher than the ones of the thrust and normal faults in the upper 5-10 km but generally lower in greater depths. In contrast to the strike-slip faults, both normal and thrust faults show a slight increase of the mean slip tendency with increasing depth below $5 \mathrm{~km}$ depth. The mean slip tendency increase with depth is higher for the thrust faults than for the normal faults.

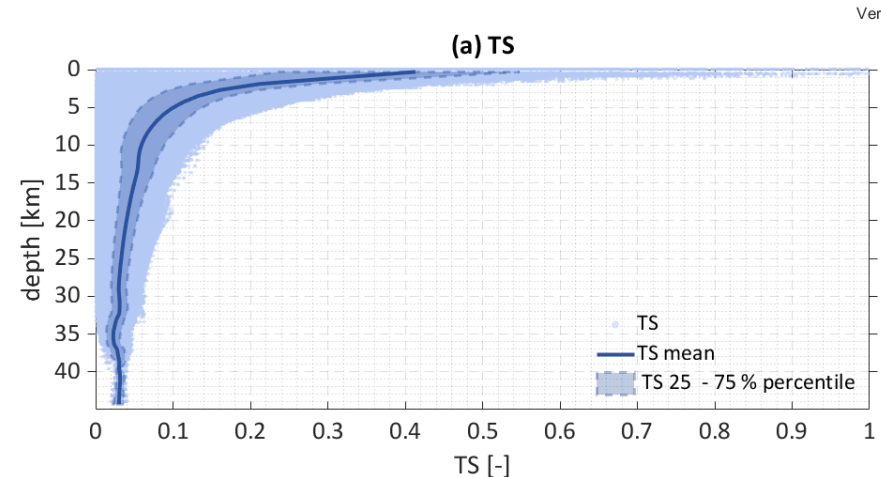

(c) TSnorm

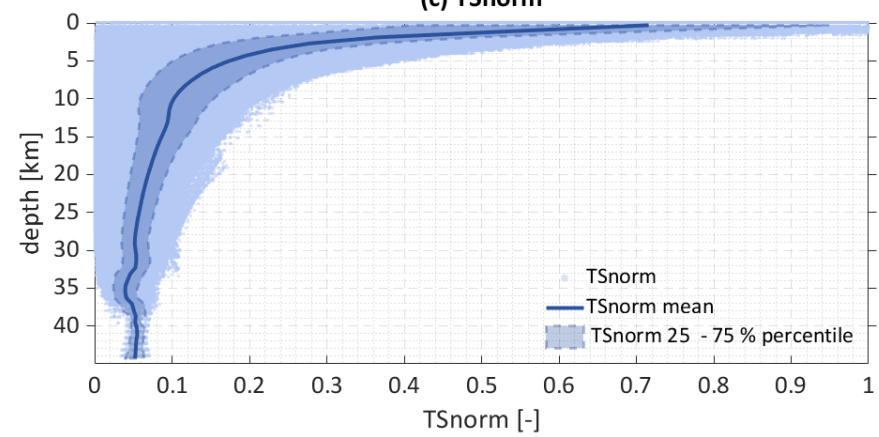

Vertical Fault Set

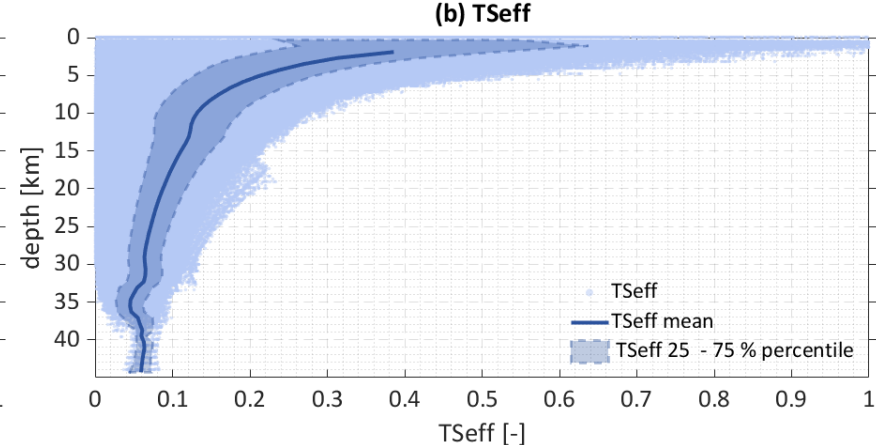

(d) TSnormeff

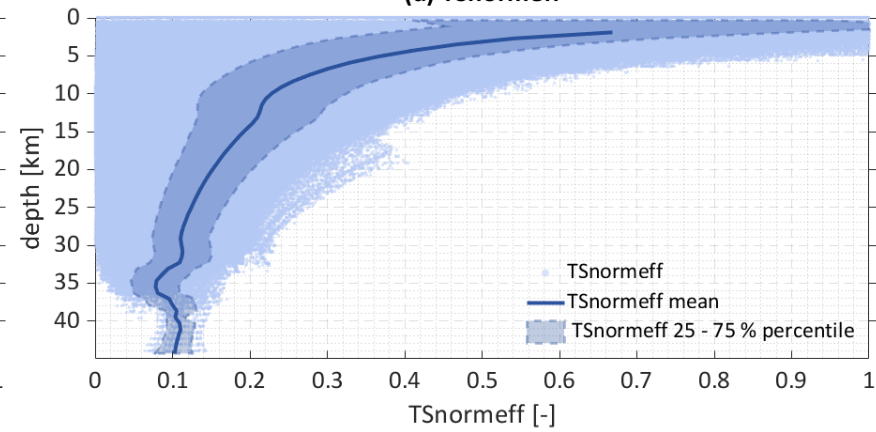

Fig. 6 All slip tendency data are plotted vs. depth for the vertical fault set. The mean slip tendency is plotted as a solid line; the $25 \%$ - 
(a) TS

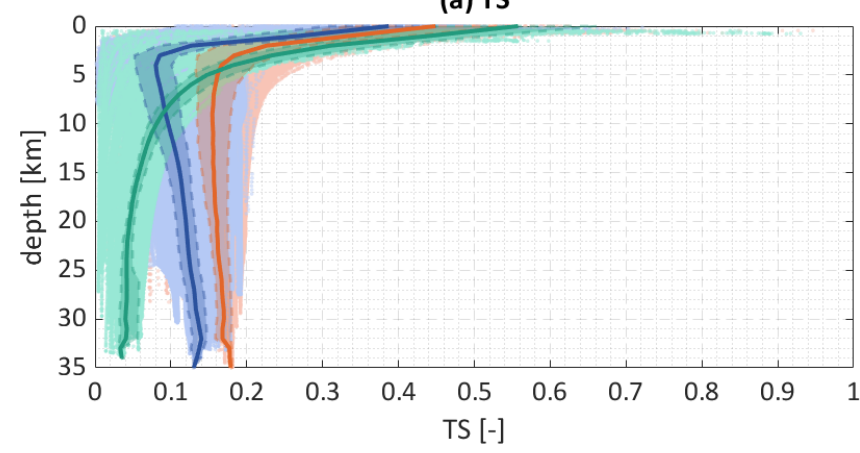

(c) TSnorm

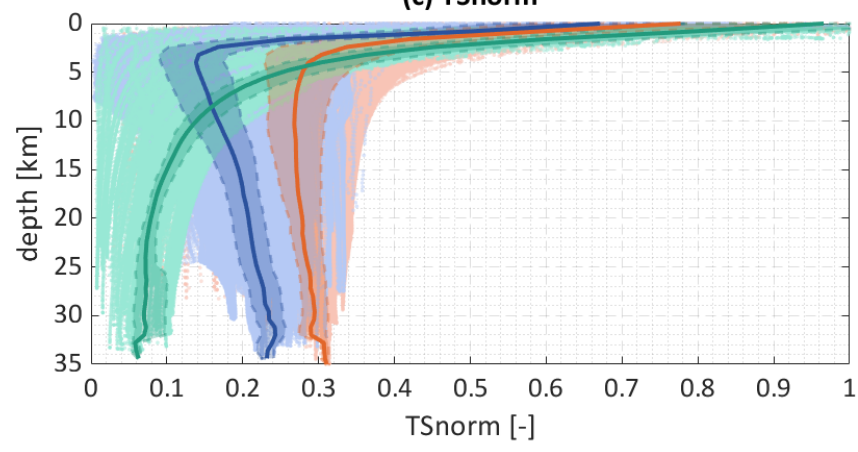

$\mathrm{NF} \quad \mathrm{TF} \quad \mathrm{SS} \longrightarrow \mathrm{NF}$ mean $\longrightarrow \mathrm{TF}$ mean $\longrightarrow \mathrm{SS}$ mean (b) TSeff

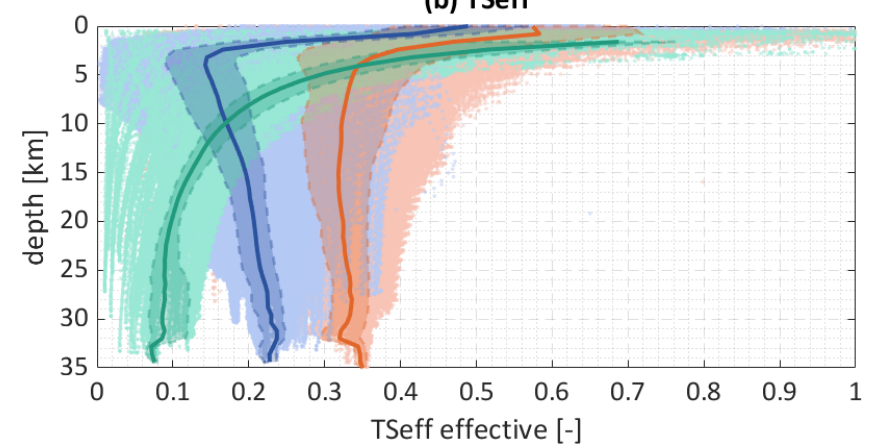

(d) TSnormeff

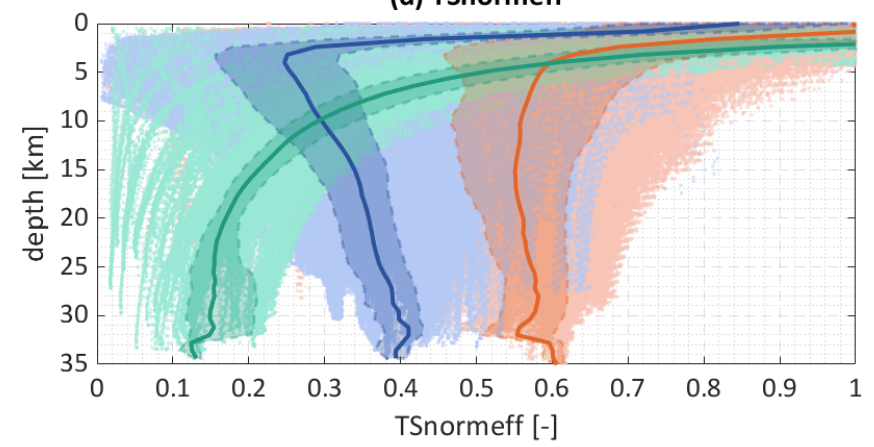

Fig. 7 All four slip tendency types at each data point of the Andersonian fault set are plotted vs. their depth. The mean slip tendency is plotted as a solid line; the $25 \%-75 \%$ percentile is shown as a shaded area. Due to the different behavior of normal, thrust and strike-slip faults, the three fault types are colored individually. Data corresponding to the normal faults are shown in orange, data corresponding to thrust faults are shown in blue and data corresponding to strike-slip faults are shown in mint color.

For normal, thrust and strike-slip faults $\sigma_{\mathrm{n}}$ increases at a similar rate with increasing depth. On the other hand, $\tau$ on strike-slip faults and the faults of the Vertical fault set increases less strongly. Since slip tendency has been defined as $\tau / \sigma_{\mathrm{n}}$, low $\tau$ leads to low slip tendencies for the strike-slip faults and the faults of the Vertical fault set. Fig. 8 shows $\tau$ for the Vertical fault set. Additionally, $\sigma_{\text {neff }}, \tau$ and the resulting $\mathrm{T}_{\text {Seff }}$ of the Landshut-Neuoetting Fault are shown exemplarily. While $\sigma_{\text {neff }}$ increases to over $250 \mathrm{MPa}, \tau$ only increases to around $20 \mathrm{MPa}$ at a depth of $30 \mathrm{~km}$ (note that the range of the color bar of $\sigma_{\text {neff }}$ is 10 times the range of the $\tau$ ). This results in $\mathrm{T}_{\text {Seff }}$ strongly decreasing with increasing depth for all faults regardless of their strike direction in the Vertical fault set. 


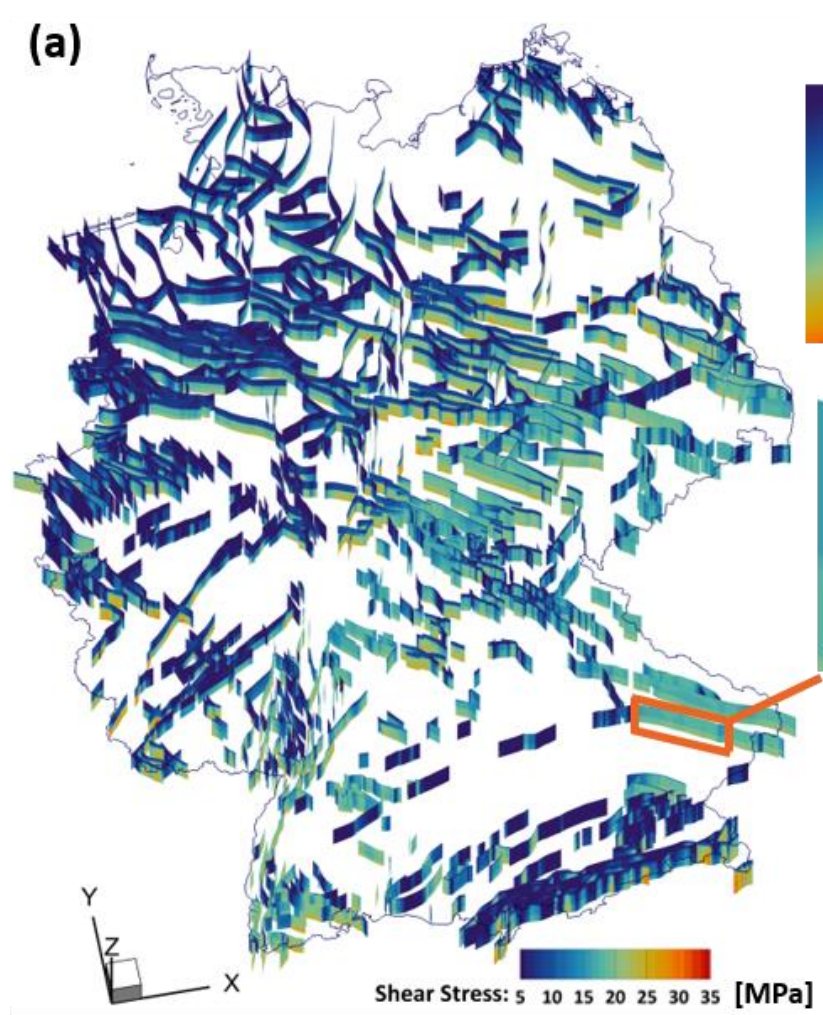

(b) Normal stress [MPa]

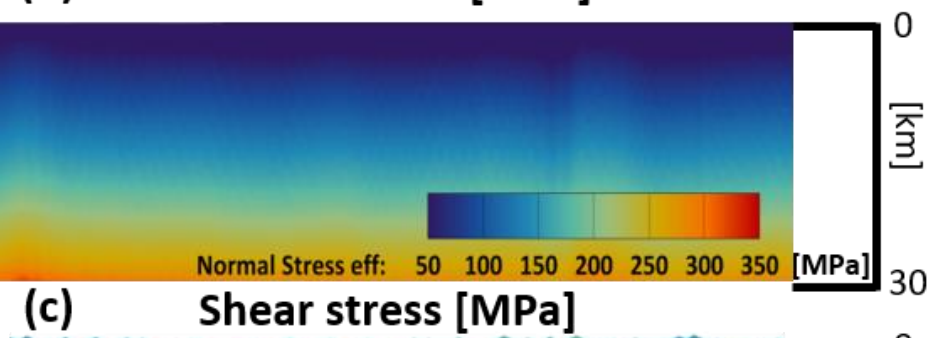

Fig. 8 (a) Shear stress $\tau$ in MPa of the vertical fault set with the color map ranging from 5 to 35 MPa. (b)-(d): Zoomed in view of the Landshut-Neuoetting Fault normal to the strike reaching to a depth of around $30 \mathrm{~km}$; (b) effective normal stress $\sigma_{\text {neff }}$ with the color map ranging from 50 to $350 \mathrm{MPa}$; (c) shear stress $\tau$ with the color map ranging from 5 to $35 \mathrm{MPa}$; (d) Tseff of the LandshutNeuoetting Fault is shown with the color map ranging between 0 and 0.7 (C) EuroGeographics for the administrative boundaries

\subsection{Influence of fault dip}

235 In order to investigate the influence of the 3D fault geometry, we compare the slip tendency histograms of the Vertical (blue), Andersonian (orange) and Semi-Realistic (mint) fault set (Fig. 9). For all four slip tendency types, the Vertical fault set shows a right skewed bell shape, the Semi-Realistic fault set displays as J-shape and the Andersonian fault set shows a bimodal distribution. The bimodal character of the Andersonian fault set is more distinct for $\mathrm{T}_{\text {Seff }}$ and $\mathrm{T}_{\text {Snormeff. The slip tendency values }}$ of the first peak are mainly concentrated on the thrust faults whereas the slip tendency values of the second peak are mainly present on normal faults.

As the normal faulting regime is predominant in most parts of the Germany model (especially in depths greater than $4 \mathrm{~km}$ ) in general $\sigma_{\mathrm{n}}$ is lower for normal faults than for thrust faults, which have been implemented with a dip of $60^{\circ}$ and $30^{\circ}$ respectively in the Andersonian fault set, leading to the bimodal distribution of $\mathrm{T}_{\mathrm{s}}$.

The more prominent bimodal distribution of $\mathrm{T}_{\text {Seff }}$ and $\mathrm{T}_{\text {Snormeff }}$ in the Andersonian fault set results from the influence of the calculation of the pore pressure as a function of depth. In combination with the normal faulting regime in most parts of the Germany model. This leads to a stronger relative reduction of $\sigma_{\text {neff }}$ of normal faults than for thrust faults. 

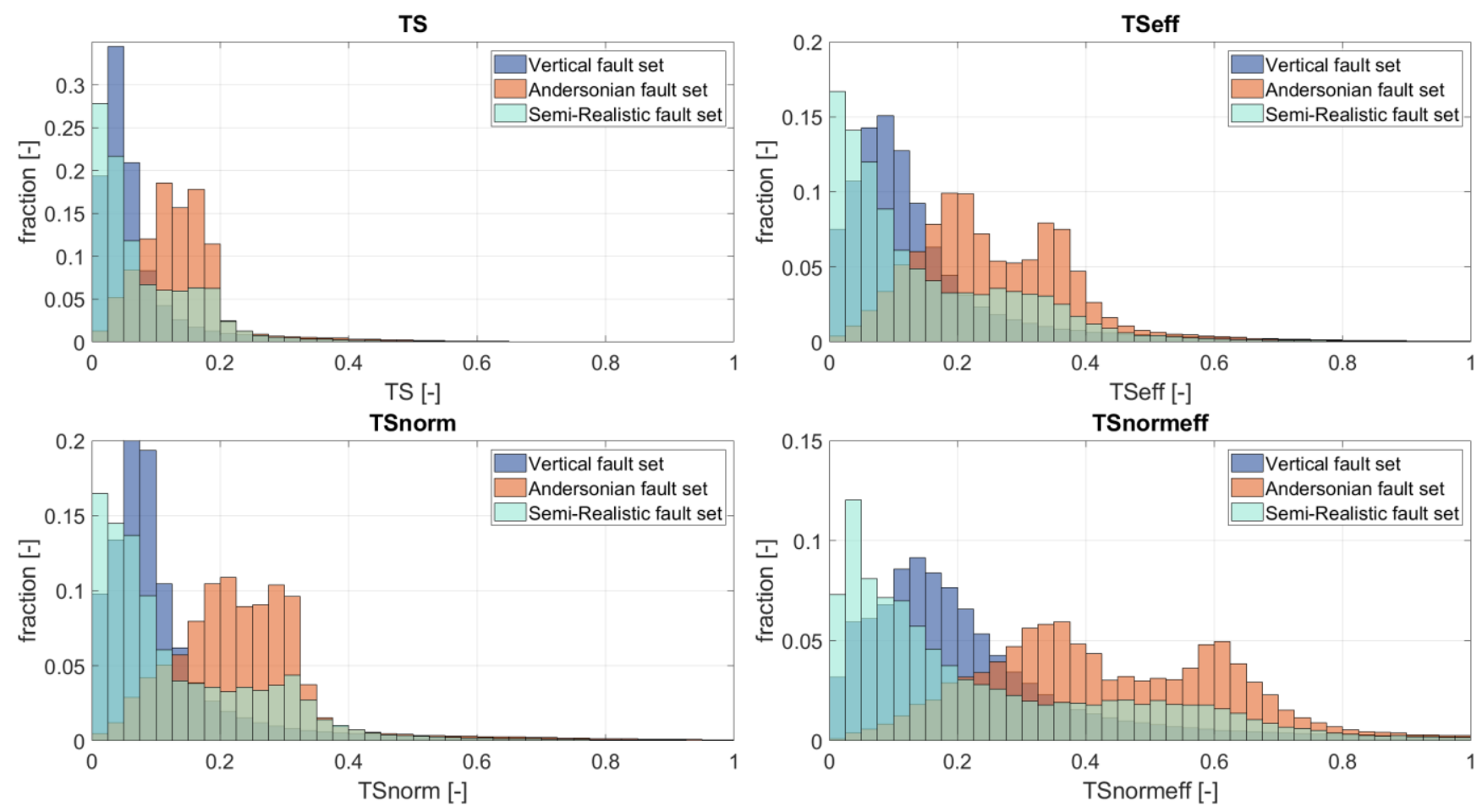

Fig. 9 Comparison of the TS histograms of the Vertical (blue), Andersonian (orange) and Semi-Realistic (mint) fault set for the four slip tendency types. Slip tendency values greater than 1 are not shown. The slip tendency values have been calculated on the nodes of the fault mesh; mesh resolution is $800 \mathrm{~m}$ for all three fault sets. Bin size is 0.025

The listric geometry of the URG in the Semi-Realistic fault set is based on DEKORP 9N (Brun et al., 1992). The URG shows high $\mathrm{T}_{\text {Seff }}$ values in the uppermost parts for both the Andersonian and the Semi-Realistic fault set. With increasing depth, the dip of the Semi-Realistic URG faults decreases until it becomes sub-horizontal. This decrease in dip coincides with a significant

$\mathrm{T}_{\text {Seff }}$ decrease. In contrast, $\mathrm{T}_{\text {Seff }}$ for the Andersonian fault geometries decreases at a significantly lower rate. This results from the fact that while $\sigma_{\text {neff }}$ increases at a similar rate for both fault types, $\tau$ of the Semi-Realistic URG increases at a much lower rate than it does for the Andersonian URG (also shown in Fig. S5). Results from the Hunsrueck Southern Border Fault, another listric fault, (derived from DEKORP 9N and 1C, Henk, 1993) show a similar behavior.

\subsection{Influence of pore pressure}

260 The use of a hydrostatic pore pressure is a major simplification since the pore pressure is not hydrostatic everywhere in Germany. Considerable overpressures have been shown for example in the Molasse basin (Drews et al., 2018; Müller et al., 1988). Müller et al. (1988) describes pore pressure gradients of up to $24 \mathrm{MPa} \mathrm{km}^{-1}$ in the vicinity of the lineament of the Alpine thrust. Fig. 10 shows $\mathrm{T}_{\text {Seff }}$ for the Alpine Thrust for pore pressure gradients of (a) $10 \mathrm{MPa} \mathrm{km}^{-1}$ (hydrostatic) (b) $16 \mathrm{MPa} \mathrm{km}$ 1 and (c) $22 \mathrm{MPa} \mathrm{km}^{-1}$. $\mathrm{T}_{\text {Seff }}$ increases drastically with increasing pore pressure. For the gradient of $16 \mathrm{MPa} \mathrm{km}^{-1} \mathrm{~T}_{\text {seff }}$ reaches values of up to 0.7 for favorably oriented segments of the fault. For a pore pressure gradient of $22 \mathrm{MPa} \mathrm{km}^{-1} \mathrm{~T}_{\text {Seff }}$ increases to 
over 0.7 for almost all parts of the fault and reaches values well in excess of 1 over large areas. Even though these pore pressure gradients are unlikely to occur over large areas of the fault, this highlights the crucial impact of the pore pressure on the fault reactivation potential.

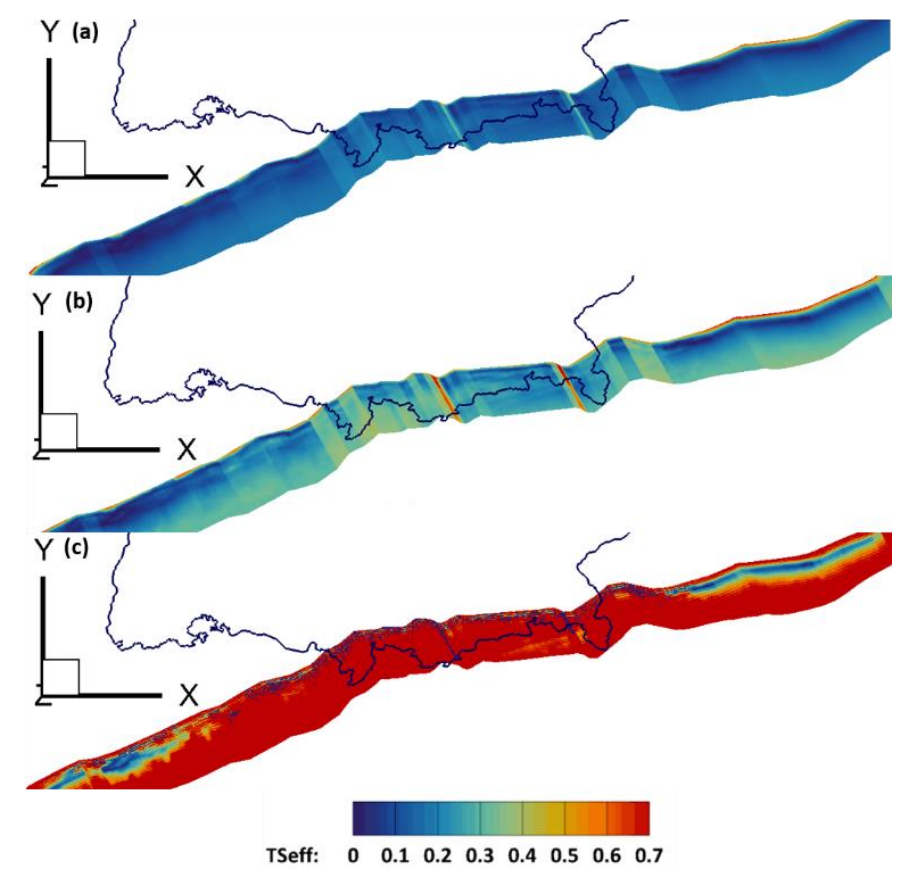

270 Fig. 10 Tseff of the Alpine Thrust for different pore pressures. (a) Tseff with hydrostatic pore pressure corresponding to a gradient of $10 \mathrm{MPa} \mathrm{km}^{-1}$; (b) TSeff for an overpressured pore pressure with a gradient of $16 \mathrm{MPa} \mathrm{km}^{-1}$; (c) Tseff for an overpressured pore pressure with a gradient of $22 \mathrm{MPa} \mathrm{km}^{-1}$. The color bar applies to all three cases. (C) EuroGeographics for the administrative boundaries

\subsection{Comparison between Slip tendency and seismicity}

275 In order to evaluate our slip tendency results, we test them qualitatively against the distribution of tectonic earthquakes. The earthquakes are taken from the seismic event catalogue of Grünthal und Wahlström (2012) that covers Western Central Europe in the past 1000 years. We selected events with $M_{w} \geq 3.5$ within the investigation area. Out of the selected 1600 seismic events, 1200 do not provide information about the hypocentral depth. For the 400 events with a given depth, the majority occurs at $8 \mathrm{~km}$ (refer to Fig. S6). The largest moment magnitudes are observed at 8 to $10 \mathrm{~km}$ depth. Therefore, we assigned a depth of

$2808 \mathrm{~km}$ for the seismic events without depth data.

Fig. 11 (a) shows the location of the seismic events with $\mathrm{M}_{\mathrm{w}} \geq 3.5$ (Grünthal and Wahlström, 2012) color-coded by their moment magnitude alongside a horizontal cross section through the Andersonian fault set at a depth of $8 \mathrm{~km}$ displaying $\mathrm{T}_{\text {Seff. }}$. The occurrence of seismic events is in good accordance with the elevated $T_{\text {Seff }}$ of the URG, the Roer Graben, the Albstadt Shear Zone, the Mariánské Lázne Fault and the Randen-Bonndorf Fault.

285 Since only a subset of the Andersonian faults set could be implemented in the Semi-Realistic fault set, there are many areas where earthquakes occur but no fault geometry is considered (Fig. 11 (b)). While the shallow sections of the URG and the 
https://doi.org/10.5194/egusphere-2022-26

Preprint. Discussion started: 8 March 2022

(c) Author(s) 2022. CC BY 4.0 License.

(c) (1)

Albstadt Shear Zone show $\mathrm{T}_{\text {Seff }}$ of 0.6 and higher, $\mathrm{T}_{\text {Seff }}$ is relatively low in a depth of $8 \mathrm{~km}$. In general, $\mathrm{T}_{\text {Seff }}$ is lower at the 8 $\mathrm{km}$ depth cross section for the Semi-Realistic fault set than for the Andersonian fault set.

While the faults with the highest $T_{\text {Seff }}$ values correlate well with the occurrence of seismic events, the absolute values are rather low, especially in $8 \mathrm{~km}$ depth and deeper, where most of the considered seismic events take place. If $\mu$ is low enough, seismicity can still occur even with $\mathrm{TS}_{\text {eff }}$ in the range below 0.4 . The range of $\mu$ of faults can vary greatly and even reach values below 0.4 for faults with fault gouge (Numelin et al., 2007; Haines et al., 2014) as a compilation by Ferrill et al. (2017) shows. For higher $\mu$, as they have been shown for different locations (Zoback and Healy, 1992; Zoback and Healy, 1985; Brudy et al., 1997) and collected by Peters (2007), $T_{\text {Seff }}$ would need to reach higher values in order to explain seismic events. This could 295 be achieved through higher $\tau$ or lower $\sigma_{\mathrm{n}}$. In order to achieve these either significant changes regarding the stress tensor from the geomechanical model of Germany or changes in the fault geometry would be required. The changes to the stress tensor required would not be warranted by the calibration data used for the model of Germany. In order to elevate $\mathrm{T}_{\text {Seff }}$ of the Franconian Line to values of 0.7 and higher, an additional $30 \mathrm{MPa}$ of $\tau$ would be required in $8 \mathrm{~km}$ depth. The required stress changes however would not fit the data from the KTB that has been used for the model calibration. On the other hand, the fault geometries are subject to major insecurities due to the sparse data available on the geometries in greater depths. As shown above, both fault strike and fault slip drastically impact the resulting slip tendency and the insecurities regarding the 3D fault geometries could therefore at least partly explain the overall low values. 
https://doi.org/10.5194/egusphere-2022-26

Preprint. Discussion started: 8 March 2022

(c) Author(s) 2022. CC BY 4.0 License.

(c) (i)
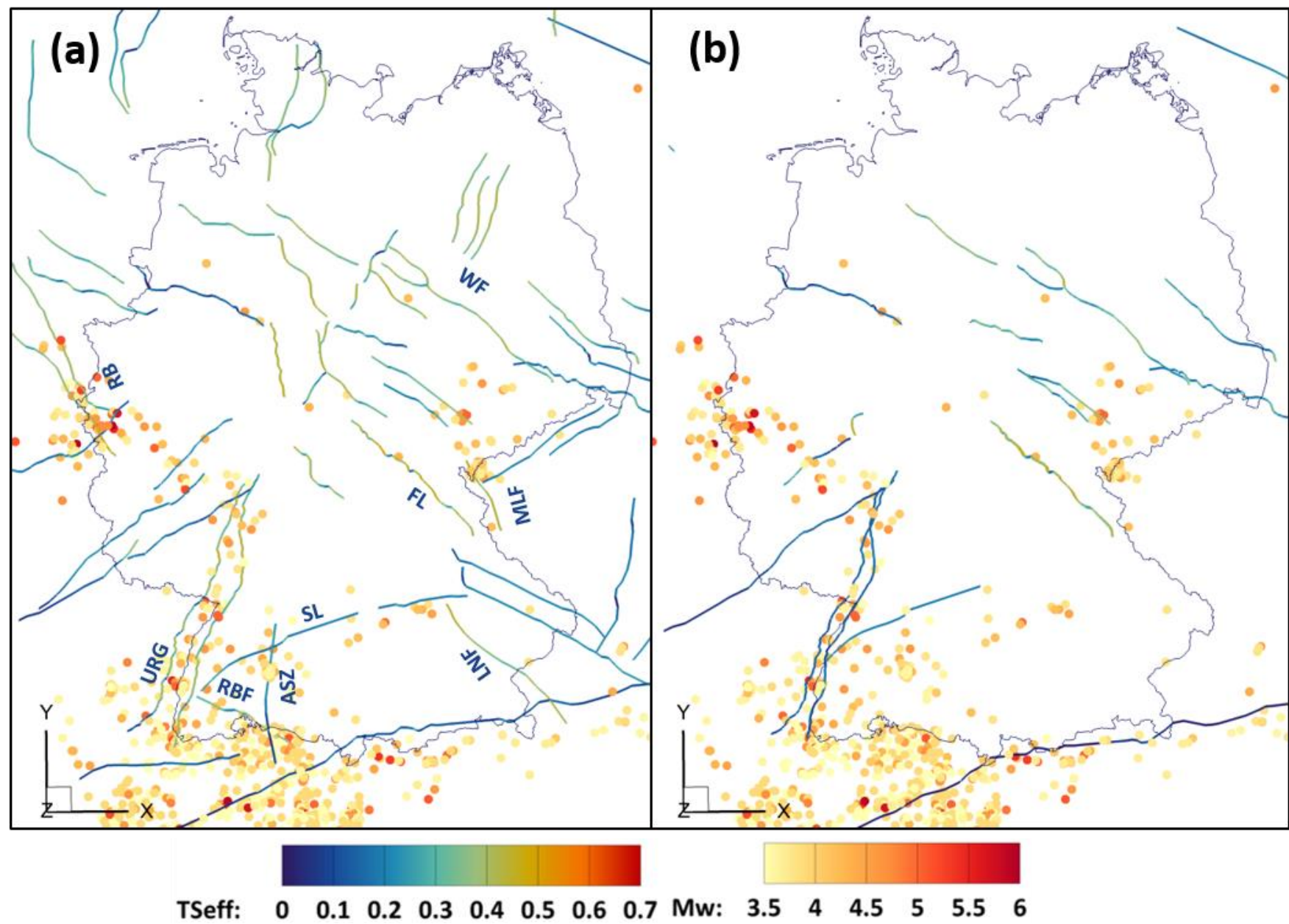

Fig. 11 Seismic events with $M_{w}>3.5$ color-coded by their seismic moment (yellow to red) are displayed alongside horizontal cross sections through the fault sets color-coded by $T_{\text {Seff }}$ (hydrostatic pore pressure) in 8 km depth. (a): Andersonian fault set; (b): SemiRealistic fault set. The color bars of $T_{\text {seff }}$ and $M_{w}$ apply to both (a) and (b). ASZ: Albstadt Shear Zone; LNF: Landshut-Neuoetting Fault; MLF: Mariánské Lázne Fault; RBF: Randen-Bonndorf Fault; RB: Roer Basin; SL: Swabian Lineament; URG: Upper Rhine (C) EuroGeographics for the administrative boundaries

$310 \quad 4.6 \quad$ Data Limitations

The relevant data for this slip tendency analysis are the stress tensor, pore pressure, frictional fault properties and fault geometry. The model Ahlers et al. (2021b), which provides the 3D absolute stress tensor for our study, has a coarse resolution and only implements a single sediment layer as well as only four upper crustal units. Tectonic faults are not implemented and thus local stress variations due to their presence are not considered in the model. Ahlers et al. (2021a) describe a good fit to

315 the stress magnitude data that are used for the model calibration. However, these are located in the uppermost kilometers of the model where we predict the overall highest slip tendencies. In greater depths, where our slip tendency results are visibly lower, no calibration data were available for the geomechanical model. 
Wide regions and depth intervals of the numerical model indicate a prevailing normal faulting stress regime. However, focal mechanisms of seismic events (Heidbach et al. 2018) indicate a possible strike-slip regime also in greater depths. In such a regime, an overestimation of the minimum horizontal stress $S_{\mathrm{hmin}}$ reduces the slip tendencies. Similarly, the underestimation of the maximum stress (either the vertical stress $S_{\mathrm{v}}$ in normal faulting stress regime or the maximum horizontal stress $S_{H \max }$ in a strike-slip stress regime) might explain the low slip tendencies.

A second major source of uncertainty results from the limited data available regarding the 3D fault geometries of the selected faults with sufficient depth extension (mostly $>5 \mathrm{~km}$ ). Only few seismic sections and geological cross sections could be used for the 3D fault geometry generation. Due to the sparse data available for most faults the 3D geometry has been deduced from only one section. The resulting geometries are therefore unlikely to properly represent the real 3D fault geometries (dip, strike, depth extent) over the entire fault lengths. As shown above, strike and dip have major influences on the resulting slip tendency. Pore pressure data are too sparse to justify the discrimination of areas of distinct pore pressure gradients and thus only a hydrostatic pore pressure could be assumed for the estimation of $\mathrm{T}_{\text {Seff }}$ and $\mathrm{T}_{\text {Snormeff }}$ with the above mentioned effects. Since data on the frictional fault properties were not available, we assumed the faults to be cohesionless. If the considered faults have cohesion greater than 0 , the resulting slip tendencies would be further reduced.

\section{Main outcome \& recommendations}

The slip tendency analysis on basis of the 3D absolute stress tensor from the geomechanical-numerical model of Germany 335 (Ahlers et al., 2021b) allowed the identification of regions with a higher reactivation potential and regions where faults are more stable. Elevated slip tendencies have been found especially for NNE-SSW and NW-SE striking faults such as the URG, the Franconian Line, the Albstadt Shear Zone, the Wittenberg Fault, the Rheinsberg Through, the Landshut-Neuoetting Fault and the Roer Graben. For the simple geometries of the Andersonian fault set, a good fit between areas of elevated slip tendencies and seismic activities could be achieved.

340 The major influence of fault geometry on the calculated slip tendency has been shown by the comparison of three fault sets. High quality information on fault geometry can be provided for example by interpreted seismic sections for large scale faults. To improve this kind of analysis, faults should be characterized by multiple seismic cross sections. The analysis also has shown the crucial influence of the pore pressure on slip tendencies for the fault sets considered. However, no spatially comprehensive pore pressure data for the entire area of Germany are available. The same applies for the frictional properties of faults, which

345 are only poorly restrained. Lastly, further and more information on the stress state in Germany is crucial for a more reliable slip tendency analysis.

Data availability The fault geometries are available under the DOI 10.5445/IR/1000143465 . 
https://doi.org/10.5194/egusphere-2022-26

Preprint. Discussion started: 8 March 2022

(c) Author(s) 2022. CC BY 4.0 License.

(c) (i)

Author contributions. Conceptualization of the project was done by AH, TH, KR, OH, FS and BM. Research and collection of fault information was done by SA and LR. Generation of 3D fault geometries and slip tendency analysis were done by LR. Evaluation and interpretation of the slip tendency results were done by LR with the support of BM, OH, KR, TH, SA and AH. LR wrote this paper with the help of all coauthors. All authors read and approved the final paper.

Acknowledgements. This study is part of the SpannEnD Project (http://www.SpannEnD-Projekt.de, last access: 25.02.2022),

355 which is supported by Federal Ministry for Economic Affairs and Energy (BMWI) and managed by Projektträger Karlsruhe (PTKA) (project code: 02E11637A).

Competing interests. The authors declare that they have no conflict of interest.

360 Financial support. This research has been supported by the Bundesministerium für Wirtschaft und Energie (grant no. 02E11637A).

\section{References}

Agemar, T., Alten, J.-A., Gorling, L., Gramenz, J., Kuder, J., Suchi, E., Moeck, I., Weber, J., V. Hartmann, H., Stober, I., Hese, F., and Thomsen, C.: Verbundsvorhaben "StörTief": Die Rolle von tiefreichenden Störungszonen bei der

365 geothermischen Energienutzung, Endbericht, 2016.

Ahlers, S., Henk, A., Hergert, T., Reiter, K., Müller, B., Röckel, L., Heidbach, O., Morawietz, S., Scheck-Wenderoth, M., and Anikiev, D.: 3D crustal stress state of Germany according to a data-calibrated geomechanical model, Solid Earth, 12, 1777-1799, https://doi.org/10.5194/se-12-1777-2021, 2021a.

Ahlers, S., Henk, A., Hergert, T., Reiter, K., Müller, B., Röckel, L., Heidbach, O., Morawietz, S., Scheck-Wenderoth, M.,

370 and Anikiev, D.: The Crustal stress state of Germany - Results of a 3D geomechnical model, TUdatalib [data set], https://doi.org/10.48328/tudatalib-437, 2021 b.

Aleksandrowski, P., Kryza, R., Mazur, S., and Zaba, J.: Kinematic data on major Variscan strike-slip faults and shear zones in the Polish Sudetes, northeast Bohemian Massif, Geol. Mag., 134, 727-739, https://doi.org/10.1017/S0016756897007590, 1997.

375 Badura, J., Zuchiewicz, W., Stepancikova, P., Przybylski, Kontny, B., and Cacon, S.: The Sudetic Marginal Fault: a young morphophotectonic feature at the ne margin of the Bohemian Massif, Central Europe, Acta Geodyn. Geomater., 148, 7-29, 2007.

Behr, H. J., Duerbaum, H. J., Bankwitz, P., Bankwitz, E., Benek, R., Berger, H. J., Brause, H., Conrad, W., Foerste, K., Frischbutter, A., Gebrande, H., Giese, P., Goethe, W., Guertler, J., Haenig, D., Haupt, M., Heinrichs, T., Horst, W., Hurtig, 380 E., and Kaempf, H.: Crustal structure of the Saxothuringian Zone; results of the deep seismic profile MVE-90(East), Z. Geol. Wissenschaft., 22, 647-770, 1994. 
https://doi.org/10.5194/egusphere-2022-26

Preprint. Discussion started: 8 March 2022

(c) Author(s) 2022. CC BY 4.0 License.

\section{(c) (i)}

Brandmayr, M., Loizenbauer, J., and Wallbrecher, E.: Contrasting PT conditions during conjugate shear zone development in the Southern Bohemian Massif, Austria, Mitt. Österr. Geol. Ges., 11-29, available at:

https://www.zobodat.at/pdf/mittgeolges_90_0011-0029.pdf, 1997.

Brückl, E., Bleibinhaus, F., GOSAR, A., Grad, M., Guterch, A., Hrubcová, P., Keller, G. R., Majdański, M., Šumanovac, F., Tiira, T., Yliniemi, J., Hegedűs, E., and Thybo, H.: Crustal structure due to collisional and escape tectonics in the Eastern Alps region based on profiles Alp01 and Alp02 from the ALP 2002 seismic experiment, Journal of Geophysical Research: Solid Earth, 112, 1109, https://doi.org/10.1029/2006JB004687, 2007.

Brudy, M., Zoback, M. D., Fuchs, K., Rummel, F., and Baumgärtner, J.: Estimation of the complete stress tensor to $8 \mathrm{~km}$ depth in the KTB scientific drill holes: Implications for crustal strength, J. Geophys. Res., 102, 18453-18475, https://doi.org/10.1029/96JB02942, 1997.

Brun, J. P., Gutscher, M.-A., and dekorp-ecors teams: Deep crustal structure of the Rhine Graben from dekorp-ecors seismic reflection data: A summary, Tectonophysics, 208, 139-147, https://doi.org/10.1016/0040-1951(92)90340-C, available at: http://www.sciencedirect.com/science/article/pii/004019519290340C, 1992.

Bundesanstalt für Geowissenschaften und Rohstoffe: TUNB-3D: 3D Modell des tieferen Untergrundes des Norddeutschen Beckens, 2021.

Cazes, M., Torreilles, G., Bois, C., Damotte, B., Galdeano, A., Hirn, A., Mascle, A., Matte, P., van Ngoc, P., and Raoult, J. F.: Structure de la croute hercynienne du Nord de la France; premiers resultats du profil ECORS, Bulletin de la Société Géologique de France, 8, 925-941, https://doi.org/10.2113/gssgfbull.I.6.925, 1985.

400 Cornet, F. H. and Röckel, T.: Vertical stress profiles and the significance of "stress decoupling", Tectonophysics, 581, 193205, https://doi.org/10.1016/j.tecto.2012.01.020, available at: http://www.sciencedirect.com/science/article/pii/S0040195112000480, 2012.

Drews, M., Bauer, W., and Stollhofen, H.: Porenüberdruck im Bayrischen Molassebecken, Overpressure in the Bavarian Molasse Basin, Erdöl Erdgas Kohle, https://doi.org/10.19225/180703, 2018.

405 Drozdzewski, G. and Dölling, M.: Elemente der Osning-Störungszone (NW-Deutschland): Leitstrukturen einer Blattverschiebungszone, scriptum online, 2018.

Duin, E.J.T., Doornenbal, J. C., Rijkers, R.H.B., Verbeek, J. W., and Wong, T.E.: Subsurface structure of the Netherlands results of recent onshore and offshore mapping, Netherlands Journal of Geosciences, 85, 245-276, https://doi.org/10.1017/S0016774600023064, 2006.

410 Ferrill, D. A., Smart, K. J., and Morris, A. P.: Resolved stress analysis, failure mode, and fault-controlled fluid conduits, Solid Earth, 11, 899-908, https://doi.org/10.5194/se-11-899-2020, 2020.

Ferrill, D. A., Morris, A. P., McGinnis, R. N., Smart, K. J., Wigginton, S. S., and Hill, N. J.: Mechanical stratigraphy and normal faulting, Journal of Structural Geology, 94, 275-302, https://doi.org/10.1016/j.jsg.2016.11.010, 2017.

Franke, W., Bortfeld, R. K., Brix, M., Drozdzewski, G., Dürbaum, H. J., Giese, P., Janoth, W., Jödicke, H., Reichert, C., 415 Scherp, A., Schmoll, J., Thomas, R., Thünker, M., Weber, K., Wiesner, M. G., and Wong, H. K.: Crustal structure of the 
https://doi.org/10.5194/egusphere-2022-26

Preprint. Discussion started: 8 March 2022

(c) Author(s) 2022. CC BY 4.0 License.

(c) (i)

Rhenish Massif: results of deep seismic reflection lines Dekorp 2-North and 2-North-Q, Geol Rundsch, 79, 523-566, https://doi.org/10.1007/BF01879201, 1990.

Geißler, V., Gauer, A., and Görne, S.: Innovative digitale Geomodelle 2020 - Teil 1, Dresden, 2014.

Geluk, M. C., Duin, E.J.T., Dusar, M., Rijkers, R.H.B., van den Berg, M. W., and van Rooijen, P.: Stratigraphy and tectonics of the Roer Valley Graben, Geologie en Mijnbouw, 73, 129-141, 1994.

GeoMol Team: GeoMol - Assessing subsurface potentials of the Alpine Foreland Basins for sustainable planning and use of natural resources - Project Report, LfU, 192 pp., 2015.

GeORG-Projektteam: Geopotentiale des tieferen Untergrundes im Oberrheingraben: Fachlich-Technischer Abschlussbericht des INTERREG-Projekts GeORG, Teil 4, Freiburg i. Br., 104 pp., 2013.

425 Grünthal, G. and Wahlström, R.: The European-Mediterranean Earthquake Catalogue (EMEC) for the last millennium, J Seismol, 16, 535-570, https://doi.org/10.1007/s10950-012-9302-y, 2012.

Grzempowski, P., Badura, J., Cacoń, S., Kaplon, J., Rohm, W., and Przybylski, B.: Geodynamics of south-eastern part of the Central European Subsidence Zone, Acta Geodynamica et Geomaterialia, 9, 359-369, 2012.

Haines, S., Marone, C., and Saffer, D.: Frictional properties of low-angle normal fault gouges and implications for low-angle normal fault slip, Earth and Planetary Science Letters, 408, 57-65, https://doi.org/10.1016/j.epsl.2014.09.034, 2014.

Healy, D. and Hicks, S. P.: De-risking the energy transition by quantifying the uncertainties in fault stability, Solid Earth, 13, 15-39, https://doi.org/10.5194/se-13-15-2022, 2022.

Heidbach, O., Ziegler, M., and Stromeyer, D.: Manual of the Tecplot 360 Add-on GeoStress v2.0, World Stress Map Technical Report, 20-02, 62 pp., 2020.

435 Henk, A.: Subsidenz und Tektonik des Saar-Nahe-Beckens (SW-Deutschland), Geol Rundsch, 82, 3-19, https://doi.org/10.1007/BF00563266, available at: https://link.springer.com/article/10.1007/BF00563266\#, 1993.

Jaeger, J. C., Cook, N. G. W., and Zimmerman, R. W.: Fundamentals of rock mechanics, 4. ed., Blackwell Publ, Malden, MA, 475 pp., 2011.

Jan Valenta, Vladimir Stejskal, and Petra Stepancikova: Tectonic pattern of the Hronov-Porici trough as seen from pole-

440 dipole geoelectrical measurements, Acta Geodynamica et Geomaterialia, 5, 185-195, available at: https://www.researchgate.net/publication/259746058_Tectonic_pattern_of_the_Hronov-Porici_trough_as_seen_from_poledipole_geoelectrical_measurements, 2008.

Jens J. Møller and Erik S. Rasmussen: Middle Jurassic - Early Cretaceous rifting of the Danish Central Graben, GEUS Bulletin, 1, 247-264, https://doi.org/10.34194/geusb.v1.4654, available at:

445 https://geusbulletin.org/index.php/geusb/article/view/4654, 2003.

Kachlík, V.: The evidence for late Variscan nappe thrusting of the Marianske Lazne Complex over the Saxothuringian terrane (west Bohemia), Journal of the Czech Geological Society, 1993.

Konon, A.: Strike-slip faulting in the Kielce Unit, Holy Cross Mountains, central Poland, Acta Geologica Polonica, 57, 415441, 2007. 
https://doi.org/10.5194/egusphere-2022-26

Preprint. Discussion started: 8 March 2022

(c) Author(s) 2022. CC BY 4.0 License.

\section{(c) (1)}

Lee, J. B. and Chang, C.: Slip tendency of Quaternary faults in southeast Korea under current state of stress, Geosci J, 13, 353-361, https://doi.org/10.1007/s12303-009-0033-1, 2009.

Littke, R., Bayer, U., Gajewski, D., and Nelskamp, S. (Eds.): Dynamics of complex intracontinental basins: The Central European Basin System, Springer, Berlin Heidelberg, 2008.

McFarland, J. M., Morris, A. P., and Ferrill, D. A.: Stress inversion using slip tendency, Computers \& Geosciences, 41, 40-

46, https://doi.org/10.1016/j.cageo.2011.08.004, 2012.

Moeck, I., Kwiatek, G., and Zimmermann, G.: Slip tendency analysis, fault reactivation potential and induced seismicity in a deep geothermal reservoir, Journal of Structural Geology, 31, 1174-1182, https://doi.org/10.1016/j.jsg.2009.06.012, 2009. Morawietz, S., Heidbach, O., Reiter, K., Ziegler, M., Rajabi, M., Zimmermann, G., Müller, B., and Tingay, M.: An openaccess stress magnitude database for Germany and adjacent regions, Geothermal Energy, 8, https://doi.org/10.1186/s40517-

$460 \quad 020-00178-5,2020$.

Müller, M., Nieberding, F., and Wanninger, A.: Tectonic style and pressure distribution at the northern margin of the Alps between Lake Constance and the River Inn, Geol Rundsch, 77, 787-796, https://doi.org/10.1007/BF01830185, 1988.

Narkiewicz, M., Maksym, A., Malinowski, M., Grad, M., Guterch, A., Petecki, Z., Probulski, J., Janik, T., Majdański, M., Środa, P., Czuba, W., Gaczyński, E., and Jankowski, L.: Transcurrent nature of the Teisseyre-Tornquist Zone in Central

465 Europe: results of the POLCRUST-01 deep reflection seismic profile, Int J Earth Sci (Geol Rundsch), 104, 775-796, https://doi.org/10.1007/s00531-014-1116-4, 2015.

Neves, M. C., Paiva, L. T., and Luis, J.: Software for slip-tendency analysis in 3D: A plug-in for Coulomb, Computers \& Geosciences, 35, 2345-2352, https://doi.org/10.1016/j.cageo.2009.03.008, 2009.

Numelin, T., Marone, C., and Kirby, E.: Frictional properties of natural fault gouge from a low-angle normal fault, Panamint

470 Valley, California, Tectonics, 26, n/a-n/a, https://doi.org/10.1029/2005TC001916, 2007.

Peters, G.: Active tectonics in the Upper Rhine Graben: Integration of paleoseismology, geomorphology and geomechanical modeling, Zugl.: Amsterdam, Vrije Univ., Diss, 2007, Logos-Verl., Berlin, 270 pp., 2007.

Pfiffner, O. A.: Thick-skinned and thin-skinned tectonics: A global perspective, Geosciences, 7, https://doi.org/10.3390/geosciences7030071, available at: https://www.scopus.com/inward/record.uri?eid=2-s2.0-

475 85028754583\&doi=10.3390\%2fgeosciences7030071\&partnerID=40\&md5=1669282e58a99dcf5df559b9129ea500, 2017.

Porpaczy, C.: Tectonic Evolution of the Budějovice Basin (Czech Republic), with special focus on the Hluboká-Fault, 2011.

Reinecker, J. and Schneider, G.: Zur Neotektonik der Zollernalb: Der Hohenzollerngraben und die Albstadt-Erdbeben,

Jahresberichte und Mitteilungen des Oberrheinischen Geologischen Vereins, 84, 391-417,

https://doi.org/10.1127/jmogv/84/2002/391, 2002.

480 Reinhold, K.: Tiefenlage der "Kristallin-Oberfläche" in Deutschland - Abschlussbericht, Bundesanstalt für Geowissenschaften und Rohstoffe, Hannover, 89 pp., 2005.

Ribbert, K.-H. and Wrede, V.: Stratigrafische und tektonische Ergebnisse der Grundgebirgsbohrungen im Umfeld des Braunkohle-Tagebaus Hambach, in: Der tiefere Untergrund der Niederrheinischen Bucht: Ergebnisse eines 
https://doi.org/10.5194/egusphere-2022-26

Preprint. Discussion started: 8 March 2022

(c) Author(s) 2022. CC BY 4.0 License.

(c) (i)

Tiefbohrprogramms im Rheinischen Braunkohlenrevier, edited by: Geologischer Dienst Krefeld, Obermann GmbH \& Co

KG, Krefeld, 33-66, 2005.

Schulz, Suchi, Dittmann, Knopf, and Müller: Geothermie-Atlas zur Darstellung möglicher Nutzungskonkurrenzen zwischen CCS und Tiefer Geothermie, 2013.

Schwarz, M. and Henk, A.: Evolution and structure of the Upper Rhine Graben: insights from three-dimensional thermomechanical modelling, Geol Rundsch, 94, 732-750, https://doi.org/10.1007/s00531-004-0451-2, 2005.

490 Sibson, R. H.: A note on fault reactivation, Journal of Structural Geology, 7, 751-754, https://doi.org/10.1016/01918141(85)90150-6, 1985.

Sibson, R. H.: Frictional constraints on thrust, wrench and normal faults, Nature, 249, 542-544, https://doi.org/10.1038/249542a0, 1974.

Suchi, E., Dittmann, J., Knopf, S., Müller, C., and Schulz, R.: Geothermal Atlas to visualise potential conflicts of interest 495 between CO2 storage (CCS) and deep geothermal energy in Germany, Zeitschrift der Deutschen Gesellschaft für Geowissenschaften, 165, 439-453, https://doi.org/10.1127/1860-1804/2014/0070, 2014.

Vadacca, L., Rossi, D., Scotti, A., and Buttinelli, M.: Slip Tendency Analysis, Fault Reactivation Potential and Induced Seismicity in the Val d'Agri Oilfield (Italy), J. Geophys. Res., 126, https://doi.org/10.1029/2019JB019185, 2021.

van Hoorn, B.: Structural evolution, timing and tectonic style of the Sole Pit inversion, Tectonophysics, 137, 239-284,

500 https://doi.org/10.1016/0040-1951(87)90322-2, available at:

https://www.sciencedirect.com/science/article/pii/0040195187903222, 1987.

Worum, G., van Wees, J.-D., Bada, G., van Balen, R. T., Cloetingh, S., and Pagnier, H.: Slip tendency analysis as a tool to constrain fault reactivation: A numerical approach applied to three-dimensional fault models in the Roer Valley rift system (southeast Netherlands), Journal of Geophysical Research: Solid Earth, 109, 233, https://doi.org/10.1029/2003JB002586,

5052004.

Yukutake, Y., Takeda, T., and Yoshida, A.: The applicability of frictional reactivation theory to active faults in Japan based on slip tendency analysis, Earth and Planetary Science Letters, 411, 188-198, https://doi.org/10.1016/j.epsl.2014.12.005, 2015.

Zoback, M. D. and Healy, J. H.: Friction, faulting, and 'in situ' stress, International Journal of Rock Mechanics and Mining 510 Sciences \& Geomechanics Abstracts, 22, 119, https://doi.org/10.1016/0148-9062(85)93053-0, 1985.

Zoback, M. D. and Healy, J. H.: In situ stress measurements to $3.5 \mathrm{~km}$ depth in the Cajon Pass Scientific Research Borehole: Implications for the mechanics of crustal faulting, J. Geophys. Res., 97, 5039, https://doi.org/10.1029/91JB02175, 1992. 